
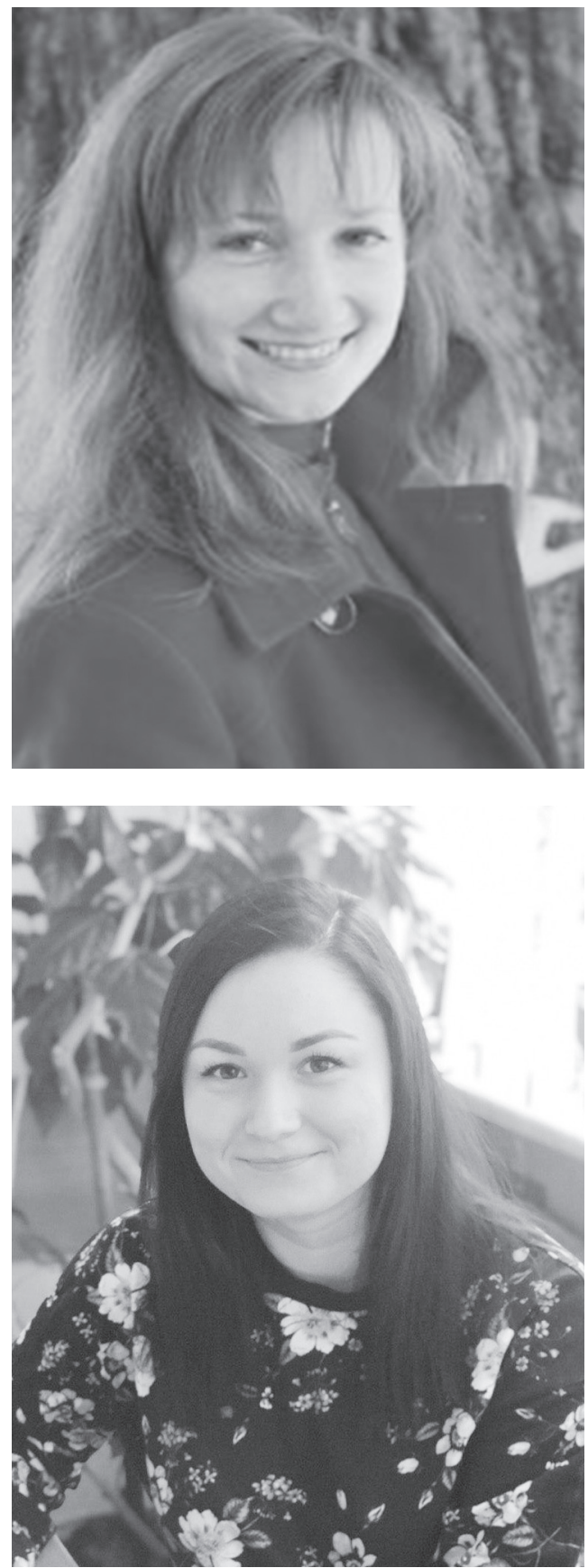

\section{Лукашевская Ульяна Тарасовна,}

аспирант, ассистент кафедры административного и финансового менеджмента, Национальньй университет “Львовская политехника", 79013, г. Львов, ул. Степана Бандеpы, 28a, 5-й учебный корпус, к. 2-б, тел.: + 38 (032) 2582630, -mail:ulya_brodka@ukr.net ORCID: 0000-0003-0270-8734
УДК 35.351.071

DOI: https://doi.org/10.32689/2617-

2224-2019-18-3-362-373

\section{Перхач Оксана Любомирівна,}

кандидат економічних наук, доцент, доцент кафедри адміністративного та фінансового менеджмент, Національний університет "Львівська політехніка", 79013, м. Львів, вул. Степана Бандери, 28a, 5-й навчальний корпус, кім. 2-б, тел.: + 38 (032) 25826 30, e-mail: Oksana.L.Perkhach@lpnu.ua

ORCID: 0000-0003-4452-4685

\section{Перхач Оксана Любомировна,}

кандидат экономических наук, доцент, доцент кафедры административного и финансового менеджмента, Национальный университет "Львовская политехника", 79013, г. Львов, ул. Степана Бандеры, 28а, 5-й учебный корпус, к. 2-б, тел.: + 38 (032)2582630,e-mail:Oksana.L.Perkhach@ Ірпи.иа

ORCID: 0000-0003-4452-4685

\section{Perkhach Oksana Liubomyriona,}

PhD in Economics, Docent, Associate Professor of the Department of Administrative and Financial Management, Lviv Polytechnic National University, 79013, Lviv, Str. Stepana Bandery, 28a, $5^{\text {th }}$ educational building, room. 2-b, tel.: + 38 (032) 2582630 , e-mail: Oksana.L.Perkhach@lpnu.ua

ORCID: 0000-0003-4452-4685

\section{Лукашевська Уляна Тарасівна,}

аспірант, асистент кафедри адміністративного та фінансового менеджменту, Наиіональний університет "Львівська політехніка", 79013, м. Львів, вул. Степана Бандери, 28а, 5-й навчальний корпус, кім. 2-б, тел.: + 38 (032) 25826 30, e-mail ulyabrodka@ukr.net

ORCID: 0000-0003-0270-8734 
Lukashevska Ulyana Tarasiona,

PhD student, assistant of the Department of Administrative and Financial Management, Lviv Polytechnic National University, 79013, Lviv, Str. Stepan Bandera, 28a, $5^{\text {th }}$ educational building, room.2-b, tel.: + 38 (032) 2582630,e-mail:ulya_brodka@ukr.net

ORCID: 0000-0003-0270-8734

\section{АРХЕТИПНІ МОДЕЛІ ПУБЛІЧНОГО УПРАВЛІННЯ}

Анотація. Представлено визначення публічного управління, його механізми та моделі. З'ясовано вплив публічного управління на суспільство. Розглянуто формування процесу публічного управління, історичні етапи розвитку архетипної моделі. На фоні створеної моделі розроблено архетипні механізми публічного управління. Розглянуто механізми публічного управління. Визначено, що інструменти публічного управління становлять ефективні засоби механізмів розвитку публічного управління, проаналізовано їх особливості. Розкрито вплив публічного управління на суспільство. Доведено необхідність розвитку механізмів. Проаналізовано різні теорії, що стосуються цієї теми. Описано діяльність публічного управління, методи та засоби класичного менеджменту, а також розроблено модель публічного управління, розглянуто базові елементи. Висвітлено теорії представників школи наукового менеджменту. Розроблено основні архетипні моделі та їх рівні. Проаналізовано процеси публічного управління із застосуванням архетипної моделі. Узагальнено наявні концептуальні та теоретичні положення. Показано необхідність нових підходів управлінського впливу. Доведено, що суспільна думка та інтереси є засадами концепції публічного управління. Висвітлено значення поняття публічного управління. Акцентовано увагу на механізмах публічного управління. Розкрито основні ознаки та принципи публічного управління. Виокремлено архетипну модель, а також стисло іiі схарактеризовано. Визначено підхід публічного управління між державними та громадськими інституціями до спільних цілей та завдань. Встановлено, що держава повинна забезпечувати та втілювати заходи на зміцнення соціальної стійкості із залученням усіх верств населення. Спільна діяльність суб'єктів суспільства потребує нових форм співробітництва.

Ключові слова: публічне управління, архетипна модель, механізми публічного управління, суспільство, державне управління.

\section{АРХЕТИПНЫЕ МОДЕЛИ ПУБЛИЧНОГО УПРАВЛЕНИЯ}

Аннотация. Представлено определение публичного управления, его механизмы и модели. Выяснено влияние публичного управления на общество. Рассмотрено формирование процесса публичного управления, исторические этапы развития архетипной модели. На фоне созданной модели разработаны архетипные механизмы публичного управления. Рассмотрены меха- 
низмы публичного управления. Определено, что инструменты публичного управления составляют эффективные средства механизмов развития публичного управления, проанализированы их особенности. Раскрыто влияние публичного управления на общество. Доказана необходимость развития механизмов. Проанализировано различные теории, касающиеся этой темы. Описана деятельность публичного управления, методы и средства классического менеджмента, а также разработана модель публичного управления, описано базовые элементы. Освещены теории представителей школы научного менеджмента. Разработаны основные архетипные модели и их уровни. Анализируются процессы публичного управления с применением архетипной модели. Сделан обзор концептуальных и теоретических положений. Показана необходимость новых подходов управленческого воздействия. Доказано, что общественное мнение и интересы являются основами концепции публичного управления. Освещено значение понятия публичного управления. Акцентировано внимание на механизмах публичного управления. Раскрыты основные признаки и принципы публичного управления. Выделена архетипная модель, а также предоставлена краткая характеристика. Определен подход публичного управления между государственными и общественными институтами к общим целям и задачам. Установлено, что государство должно обеспечивать и воплощать меры на укрепление социальной устойчивости с привлечением всех слоев населения. Совместная деятельность субъектов общества требует новых форм сотрудничества.

Ключевые слова: публичное управление, архетипная модель, механизмы публичного управления, общество, государственное управление.

\section{ARCHETYPAL MODELS OF PUBLIC ADMINISTRATION}

Abstract. The article contains relevant information for the modern world. The paper describes the definition of public administration, its mechanisms and models. The influence of public administration on society is revealed. The formation of the public administration process, the historical stages of the development of an archetype model are considered. The archetypal mechanisms of public administration are developed on the background of the created model. The understanding of mechanisms of public administration is considered. It has been determined that public administration tools constitute effective means for mechanisms of development of public administration, their features are analyzed. The influence of public administration on society is revealed.

The necessity of development of mechanisms is proved. Different theories related to this topic are analyzed. The activities of public administration, methods and means of classical management, as well as developed a model of public administration described the basic elements are explored in the article. The theory of representatives of the school of scientific management is considered. The basic archetype models and their levels are developed. The processes of public management using an archetype model are analyzed. The existing conceptual and theoretical positions are summarized. The necessarily of new approaches of managerial 
influence is revealed. It is proved that public opinion and interests are the principles of the concept of public administration. The concepts of public administration as well as mechanisms are considered. The emphasis is on the mechanisms of public administration. The main features and principles of public administration are revealed. An archetypal model is also singled out, and a brief description is provided. The approach of public administration between state and public institutions to common goals and objectives is determined. It is established that the state should ensure and implement measures to strengthen social stability with the involvement of all strata of the population. Joint activity of the subjects of society requires new forms of cooperation.

Keywords: public management, archetype model, mechanisms of public administration, society, governmental management.

Постановка проблеми. Процеси, що відбуваються в сучасному суспільстві характеризують різноманітні напрями впливу. На сьогодні наука розглядає підходи до стабілізації таких процесів як соціальне, політичне та економічне середовище. Використання інструментів управління у сфері публічної влади передбачає нові відносини між громадськістю і владою та грунтується на національній архетипіці. Зазначені моделі публічного управління базуються на соціально-економічній моделі та архетипній парадигмі. В умовах реформування державного управління в Україні тема даного дослідження набуває все більшої актуальності.

Аналіз останніх досліджень та публікацій. Вагомий внесок у вивчення державно-політичних інститутів, форм правління і політичних систем внесли такі дослідники, як Е. Баркер, Д. Коул, Г. Ласки, Ч. Меннінг, У. Робсон, Г. Файнер. Представники школи наукового (класичного) менеджменту, а саме: Л. Уайт, Ф. Тейлор, Дж. Муні, Ф. і Л. Гілберт,
Г. Емерсон, Г. Форд вважали, що система публічного адміністрування має орієнтуватися на досягненні поставленої мети 3 максимальною ефективністю за мінімальних витрат. Для них було характерним визнання існування найтіснішого зв'язку між теорією публічного адміністрування і наукою управління приватними підприємствами.

Метою статті є дослідження історичних етапів розвитку архетипних моделей публічного управління та їх інституційних основ.

Виклад основного матеріалу. Публічне управління спирається на універсальні основоположення архетипіки, зокрема на ідею природного права - засновниками цієї ідеї є Аристотель, стоїки та Цицерон, на ідею держави як гаранта природного права, на ідеї конституювання закону та держави в акті вільного волевиявлення людини і на ідеї народу, якому властиві суверенне право та влада.

Публічне управління поєднуе владу, бізнес та суспільство, створюе підстави для побудови солідарно- 
го суспільства і має відповідати постулатам громадянського суспільства.

Формування процесу публічного управління відповідає викликам сучасності, розкривається перед усім суспільством та вимагає визначення методології як системи знань про метод, під яким розуміють сукупність практичних інструкцій. Дотримання цих інструкцій забезпечує досягнення бажаних результатів.

Відмінність публічного управління від інших управлінських концептів полягає в тому, що воно базується на [1]:

- самодіагностиці проблеми;

- самоформулюванні;

Історичні етапи розвитку архетипної моделі публічного управління $[1 ; 2 ; 7 ; 8]$

\begin{tabular}{|c|c|c|}
\hline $\begin{array}{c}\text { Iсторичний } \\
\text { період }\end{array}$ & Характеристика публічного управління & $\begin{array}{c}\text { Архетипна } \\
\text { модель }\end{array}$ \\
\hline $\begin{array}{l}\text { 9-7 тис. років } \\
\text { до н. е. } \\
\text { приблизно до } \\
\text { XVIII ст. }\end{array}$ & $\begin{array}{l}\text { Стародавні греки (Платон) приділяли особливу увагу } \\
\text { питанням організації та управління виробничими про- } \\
\text { цесами, піклувалися про чітку спеціалізацію працівни- } \\
\text { ків. Сократ розглядає управління як особливу сферу } \\
\text { людської діяльності. Він говорив, що головне в управ- } \\
\text { лінні - поставити потрібну людину на потрібне місце, і } \\
\text { домогтися виконання поставлених перед нею завдань }\end{array}$ & Філософська \\
\hline $1776-1890$ pp. & $\begin{array}{l}\text { Переворот у виробничих відносинах пов'язаний з про- } \\
\text { мисловою революцією, що почалася в середині XVIII } \\
\text { ст. З промисловою революцією пов'язані три рівні } \\
\text { управління: верхнє, середнє і нижнє. На виробництві } \\
\text { з'явився майстер. На цьому етапі розвитку управлін- } \\
\text { ня тільки намітилася тенденція переходу від принципу } \\
\text { нагляду за робітниками до принципу організації праці } \\
\text { на наукових засадах. Великий внесок у формування } \\
\text { науки управління зробили англійські політекономи Ві- } \\
\text { льям Петті, Адам Сміт (проаналізували форми поділу } \\
\text { праці і дав характеристику обов'язків державця і дер- } \\
\text { жави) і Роберт Оуен (звернув увагу та дав оцінку ролі } \\
\text { людського фактора на виробництві; йому належать } \\
\text { ідеї гуманізації управління виробництвом, покращен- } \\
\text { ня умов праці) }\end{array}$ & Індустріальна \\
\hline $1856-1960$ pp. & $\begin{array}{l}\text { Наука про управління постійно розвивається. Життя } \\
\text { змушувало шукати більш систематизовані підходи до } \\
\text { управління. Виникнення великих за масштабом ви- } \\
\text { робництв забезпечило роботою великі групи людей, а } \\
\text { це означало, що власники більше не могли спостері- } \\
\text { гати за діяльністю всіх робітників. З цією метою навча- } \\
\text { ли кращих робітників, щоб вони могли представляти } \\
\text { інтереси власників на робочих місцях. Це були перші } \\
\text { менеджери }\end{array}$ & Системна \\
\hline 1960 - наш час & $\begin{array}{l}\text { Пізніші теорії управління розроблялися в основному } \\
\text { представниками Школи науки управління (кількісна } \\
\text { школа - Акофф, Гольдбергер, Клейн). Становлення } \\
\text { школи пов'язано з розвитком математики, статистики, } \\
\text { інженерних наук та інших суміжних з ними сфер знань }\end{array}$ & $\begin{array}{l}\text { Інженерно- } \\
\text { інформаційна }\end{array}$ \\
\hline
\end{tabular}


- самовизначенні кращого варіанта політики;

- самовизначенні проблеми;

- самопропозиції вирішення проблеми;

• самоприйнятті плану дій;

- самоконтролі й самооцінці;

- передбачає залучення архетипів демократії.

Архетипні моделі управління це послідовність дій, реалізація яких забезпечує здійснення публічного управління відповідними органами або їх посадовими особами шляхом поступових перетворень у стані об’єктів публічного адміністрування [2]. Важливою складовою управлінської моделі є принципи, дотримання яких забезпечує створення умов для ефективного вияву об'єктивних законів.

Дія механізмів, які передбачають реалізацію архетипних моделей державного управління, передбачає урахування як управлінських принципів, так і тих, що стосуються певної галузі, пов'язаних із законами функціонування економіки чи соціуму або окремих сфер його життєдіяльності [3]. До складу архетипної моделі публічного управління насамперед мають бути включені процесні механізми, що реалізуються Президентом України, Верховною Радою України, органами державної виконавчої влади, органами юстиції та органами місцевого самоврядування [4].

Оскільки архетипні моделі публічного управління, що здійснюються органами державної влади та місцевого самоврядування на різних рівнях управління, мають свої особливості та є досить складними, то для них мають бути розроблені ок- ремі процесні механізми. Прикладами таких механізмів є механізм врегулювання соціально-трудових відносин Міністерством праці та соціальної політики України, механізм управління охороною здоров’ я відповідним головним управлінням обласної державної адміністрації, механізм управління комунальною власністю міста тощо [5].

На сьогодні розвиток архетипних моделей публічного управління відбувається за допомогою розроблення та втілення відповідних управлінських механізмів, що утворюють умови для актуального та ефективного розв'язання присутніх у цій сфері розбіжностей.

Механізми публічного управління - це спеціальні методи, що забезпечують здійснення регулюючого впливу публічних адміністрацій на соціально-економічні територіальні системи різних рівнів (села, селища, райони у містах, міста, райони, області, Автономна Республіка Крим, уся країна) з метою забезпечення гідних умов життєдіяльності людей, що проживають у державі, та громадян України, що тимчасово проживають за їі межами.

Діяльність публічного управління повторює методи та засоби класичного менеджменту: адміністративні, економічні та соціально-психологічні. Ці елементи входять до складу механізму публічного управління соціально-економічними процесами, а публічне управління - це єдність таких складових, як публічне адміністрування, взаємодія органів державної влади та місцевого самоврядування $з$ громадянами, здійснення процедур контролю та процес управ- 
ління. Виходячи $з$ потреб часу цей складний механізм удосконалюється [6].

Архетипна модель публічного управління має містити всі елементи та складові публічного управління, враховувати вплив чинників зовнішнього та внутрішнього середовища, а також грунтуватися на принципах громадянського суспільства [7].

Базові елементи публічного управління $є$ різноспрямованими щодо базових архетипів (рис. 1). Необхідним $є$ розгляд концептуальних засад архетипів публічного управління суспільством [8]. Основою такого управління є архетипи демократії, а на рівні держави набирає публічності.

Модель публічного управління це сукупність форм, методів та інструментів адміністрування. Самі по собі форми, методи та інструменти не забезпечують бажаного впливу на об'єкт [9]. Інший науковець вважає, що модель публічного управління це система взаємозв'язків економічних явищ, які виникають за певних умов під впливом початкового імпульсу, а також містить певну послідовність економічних явищ: його складовими водночас виступають вхідне і вихідне явище, а також весь процес, який відбувається в інтервалах між ними [10].

На думку Д. Лернера [12] та інших науковців найбільшу користь управлінські науки можуть принести при розв'язанні проблем середнього рівня, таких, як прогнозування наслідків конкретних парламентських проектів або оцінювання економічної дії певних пропозицій з оподаткування (психологічний підхід).

А. Файоль [13] сформулював “Теорію адміністраціі” (заклав ос-

\begin{tabular}{|c|c|c|c|}
\hline \multicolumn{4}{|c|}{ Інституційна основа архетипної моделі публічного управління: } \\
\hline \multicolumn{2}{|c|}{$\begin{array}{l}\text { • держава; } \\
\text { • система органів виконавчої влади; } \\
\text { • громадські організації; } \\
\text { • суб'єкти господарської діяльності; } \\
\text { • суспільство тощо }\end{array}$} & \multicolumn{2}{|c|}{$\begin{array}{l}\text { • суспільний договір, що трактує грома- } \\
\text { дянське суспільство як результат конвен- } \\
\text { ції соціальних феноменів (інститутів); } \\
\text { - закони (право); } \\
\text { • сукупність правових норм, що регла- } \\
\text { ментують організаційну структуру систе-- } \\
\text { ми органів виконавчої влади і процеси ї̈ } \\
\text { функціонування та розвитку тощо }\end{array}$} \\
\hline \multicolumn{4}{|c|}{$\begin{array}{c}\text { Типи архетипної } \\
\text { моделі публічного } \\
\text { управління: }\end{array}$} \\
\hline $\begin{array}{c}\text { Економічна } \\
\text { (модель публічного } \\
\text { управління банківською, } \\
\text { грошово-валютною, } \\
\text { інвестиційною, інно- } \\
\text { ваційною, кредитною, } \\
\text { податковою, страховою } \\
\text { діяльністю тощо) }\end{array}$ & $\begin{array}{r}\text { Mс } \\
\text { (сукупніс- } \\
\text { ністрати } \\
\text { еконо } \\
\text { стимулі } \\
\text { державн } \\
\text { високоес }\end{array}$ & $\begin{array}{l}\text { ційна } \\
\text { андно-адмі- } \\
\text { соціально- } \\
\text { х та інших } \\
\text { спонукають } \\
\text { ужбовців до } \\
\text { зної роботи) }\end{array}$ & $\begin{array}{c}\text { організаційна } \\
\text { (об'єкти, суб'єкти публічного } \\
\text { управління, їх цілі, } \\
\text { завдання, функції, методи } \\
\text { управління та організації } \\
\text { структури, а також результа- } \\
\text { ти їх функціонування) }\end{array}$ \\
\hline
\end{tabular}

Рис. 1. Інституційні основи та типологія архетипної моделі публічного управління 
новоположні принципи управління школи “наукового менеджменту”). Він стверджував, що пропоновані положення й установки є універсальними та можуть застосовуватися майже в усіх сферах суспільного життя: економіці, системі публічного адміністрування, армії і т. д. Файоль вважав, що управляти - означає передбачати, організовувати, розпоряджатися, координувати і контролювати.

Отже, модель публічного управління - це сукупність інструментів адміністрування, форм та методів, що мають за мету реалізувати потреби людей та вирішення проблем за рахунок державного впливу на основі встановлених норм.

Нині реалізація процесу публічного управління відбувається за допомогою розроблення та втілення відповідних управлінських механізмів, що утворюють умови для актуального та ефективного розв'язання присутніх у цій сфері розбіжностей.

Для проведення глибинних реформ нині в Україні склалася сприятлива ситуація, через те, що в суспільстві існує багато невирішених проблем та проблемних ситуацій. Потрібно залучати інститути громадянського суспільства до прийняття державних рішень, створити необхідні умови для формування і зміцнення розвитку партнерських відносин між владою та суспільством.

У загальному розумінні публічне управління являє собою організацію діяльності відповідно до вимог об'єктивних законів, реалізацію та організацію цілеспрямованих впливів. Публічне адміністрування розглядає управління як вплив на суспільство
3 метою організації та координації їх діяльності у процесі життєдіяльності. Публічне управління є визначним елементом адміністрування, оскільки відкриває перед суспільством можливості відносно влади.

Для того, щоб здійснити перерозподіл між адміністративними та політичними функціями у публічному управлінні, необхідно використати ефективні методи та технології управління, а також впровадити сучасні демократичні принципи організації діяльності органів публічного управління: спеціалізовані, структурні та загальносистемні. Публічні організації, органи влади та бізнес-структури повинні забезпечувати процес вироблення засобів в економічній системі для повноцінного функціонування та розвитку всіх сфер суспільства.

Основні архетипні моделі системи управління (див. рис. 2):

1. Централізована - здійснюється органами державної влади, на всіх рівнях управління. Вони формуються урядом або главою держави.

2. Англо-Американська - здійснюється органами місцевого самоврядування, управління на всіх рівнях, крім державного.

3. Європейська змішана еліта поєднання перших двох моделей на місцевому рівні, здійснюється управління органами місцевого самоврядування.

4. Європейська змішана з розділеною ієрархією - здійснюється лише місцевою державною адміністрацією на рівні області та району управління [11].

Кожній архетипній моделі відповідають чотири рівні: 


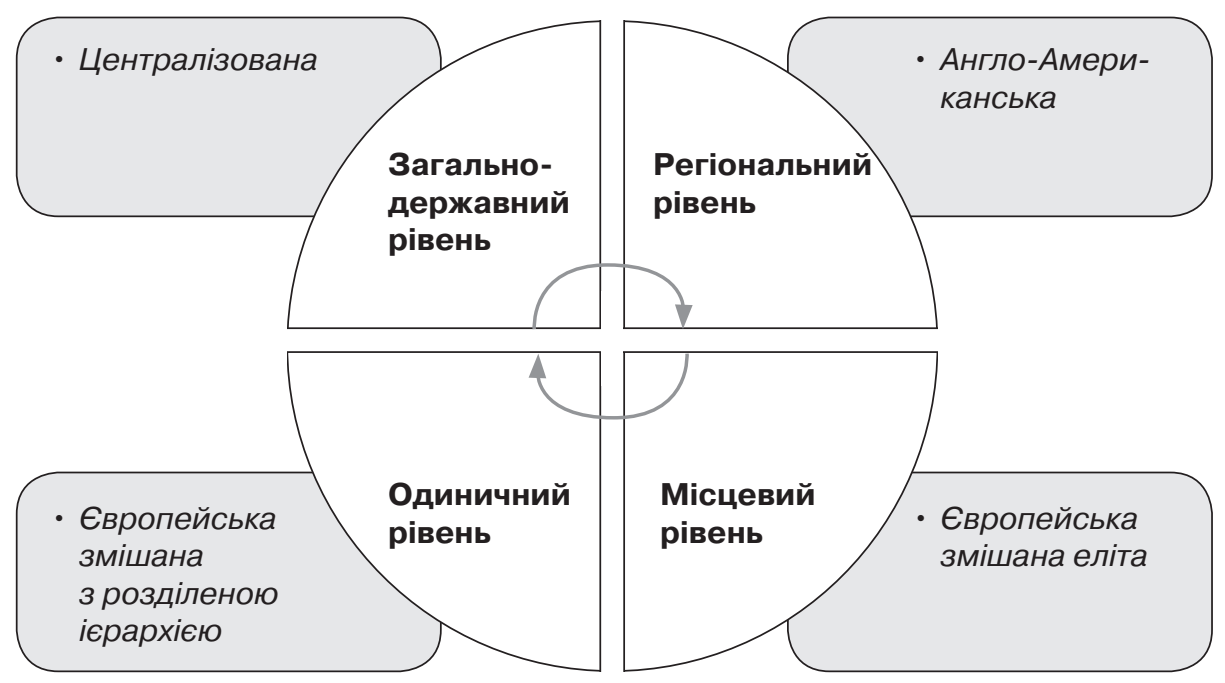

Рис. 2. Основні архетипні моделі управління та їх рівні

1. Загальнодержавний - визначаються пріоритети, а також цілі загальноекономічного розвитку країни та регіональної економіки, розробляються програми державного та регіонального соціально-економічного розвитку, фінансова та податкова політика. Закріплюються функції міждержавних відносин, екологічного захисту, регулювання грошового обігу, оборони, оподаткування за центральними органами влади. Державна форма власності переважає.

2. Регіональний - підприємницькі, регіональні та галузеві інтереси узгоджуються. Область є основним суб'єктом управління.

3. Місцевий - щодо власних інтересів територіальних громад реалізується державна регіональна політика.

4. Одиничний - узгодження окремого суб'єкта (окремого села, селища тощо) з програмою розвитку та діяльності щодо реалізації їхніх інтересів.

Згідно $з$ цими моделями акцент робиться на організаційні та еко- номічні інструменти - публічні адміністрації відрізняються організаційною гнучкістю. Інструменти економічного механізму легше застосовувати, оскільки вони є зрозумілі та забезпечують швидку реакцію.

Щодо сутності моделей ефективного публічного управління аналіз публікацій дає можливість зробити висновок, що всі вони мають відповідати трьом основним критеріям:

- цілісності;

- комплексності;

- збалансованості.

Публічне управління зобов’язане представляти і забезпечувати комплексні потреби і цілі життя людей через функціонування своїх управлінських компонентів. До ефективних факторів публічного управління належать: мотивація, ставлення до праці, знання, вміння, здібності, ініціативність, відповідальність.

Отже, результативність та ефективність публічного управління визначається дією якісних чинників технічного, політичного, організа- 
ційного, морально-ідеологічного та соціально-психологічного характеру. У високорозвиненій ринковій економіці механізми публічного управління - це оптимальне поєднання притаманних засад товарному виробництву, цілеспрямованої політики державного регулювання економічних процесів та публічно-приватного партнерства.

Висновки. Архетипна модель формується під впливом суспільного та політичного розвитку держави. Механізми публічного управління щоразу оновлюються відповідно до вимог часу та оптимізують регулювання державної політики, економічних процесів.

Публічне управління вважається ефективним, коли представляє та забезпечує потреби людей. На сьогодні набуває особливої важливості питання щодо залучення інститутів громадянського суспільства до прийняття державних рішень, створення необхідних умов для формування i зміцнення розвитку партнерських відносин між владою та суспільством. Визначено, що модель публічного управління - це сукупність інструментів адміністрування, форм та методів, основною метою яких $є$ реалізація потреб людей та вирішення проблем за рахунок державного впливу відповідно до встановлених норм. Моделі публічного управління мають відповідати основним своїм критеріям: цілісності, комплексності та збалансованості. Архетипні моделі публічного управління визначені на основі рівнів управління. Саме розбудова інституційно-архетипного середовища та створення механізмів забезпечить успішність виконання широкого кола державницьких завдань.

\section{СПИСОК ВИКОРИСТАНИХ ДЖЕРЕЛ}

1. Амосов О. Ю., Гавкалова Н. Л. Концептуальні засади публічного управління: архетипний підхід / О. Ю. Амосов, Н. Л. Гавкалова / / Публічне управління: теорія та практика. - Вип. 1. - К., 2015. - С. 8-12.

2. Амосов О. Ю., Гавкалова Н. Л. Моделі публічного адміністрування (архетипова парадигма) / О. Ю. Амосов, Н. Л. Гавкалова // Публічне управління: теорія та практика. К., 2013. - C. 6-13.

3. Бакуменко В. Д., Попов С. А. Парадигма інноваційного розвитку суспільства: сучасні концепції реформування публічного управління / В. Д. Бакуменко, С. А. Попов // Ефективність державного управління. - О., 2015. - С. 21-28.

4. Козак B. I. Публічне управління в системі координат української державності / В. I. Козак // Ефективність державного управління.Вип. 1. - Л., 2015. - С. 64-70.

5. Колесникова К. О. Співвідношення державного управління та публічного адміністрування у процесі суспільної трансформації / К. О. Колесникова //Публічне управління: теорія і практика. - Вип. 3. - Переяслав-Хмельницький, 2013. С. 41-45.

6. Оболенсъкий О., Лукін С. Публічне управління: публічна сфера, публічне право і публічна політика-співвідношення понять / О. Оболенський, С. Лукін // Державне управління та місцеве самоврядування. - Вип. 2. - Х., 2013. C. 3-11.

7. Обушна Н. I. Публічне управління як нова модель організації держав- 
ного управління в Україні: теоретичний аспект / Н. І. Обушна // Ефективність держ. управління. Вип. 1. - Херсон, 2015. - С. 53-63.

8. Приходченко Л. Л. Сутність механізму забезпечення ефективного державного управління / Л. Л. Приходченко // Теорія та практика державного управління. - Вип. 3. - Х., 2010. - C. 3-12.

9. Приходченко Л. Л. Структура механізму державного управління: взаємозв'язок компонентів та фактори впливу на ефективність / Л. Л. Приходченко // Вісн. Нац. академії держ. управління при Президентові України. - Вип. 2. - О., 2009. - C. 105-112.

10. Шаров Ю. П. Демократичні зміни в публічному управлінні: програмно-цільова ідеологія здійснення / Ю. П. Шаров // Вісн. Академії митної служби України. Серія: Державне управління. - Вип. 1. - К., 2000. - C. 52-57.

11. Шаров Ю. П., Чикаренко I. Свропейські стандарти публічного управління: проекція на муніципальний рівень / Ю. П. Шаров, І. Чикаренко // Держ. упр. та місцеве самоврядування: зб. наук. пр. - Д.: ДРІДУ НАДУ, 2010. - С. 295-304.

12. Lerner D., Coleman J., Dore R. Modernization [w:] International Encyclopedia of the Social Sciences. NY, 1968, Vol. 10. - 386 p.

13. Файоль А., Емерон Г., Тейлор I., Форд Г. Управление - это искусство. - М., 1992. - 349 с.

\section{REFERENCES}

1. Amosov O. Yu. EF Havkalova N. L. (2015). Kontseptual'ni zasady publichnoho upravlinnia: arkhetypnyj pidkhid [Conceptual principles of public management: an archetypical approach]. Publichne upravlinnia: teoriia ta praktyka vyp. 1, 8-12 [in Ukrainian].

2. Amosov O. Yu. E F Havkalova N. L. (2013). Modeli publichnoho administruvannia (arkhetypova paradyhma) [Models of public administration (archetype paradigm)]. Publichne upravlinnia: teoriia ta praktyka, 6-13 [in Ukrainian].

3. Bakumenko V. D. E. Popov S. A. (2015). Paradyhma innovatsijnoho rozvytku suspil'stva: suchasni kontseptsii reformuvannia publichnoho upravlinnia. [Paradigm of innovative society development: modern concepts of reforming public administration]. Efektyvnist' derzhavnoho upravlinnia, 43, 21-28 [in Ukrainian].

4. Kozak V. I. (2015). Publichne upravlinnia v systemi koordynat ukrains'koi derzhavnosti. [Public administration in the coordinate system of Ukrainian statehood]. Efektyvnist' derzhavnoho upravlinnia 44 (1), 64-70 [in Ukrainian].

5. Kolesnykova K. O. (2013). Spivvidnoshennia derzhavnoho upravlinnia ta publichnoho administruvannia $u$ protsesi suspil'noi transformatsii. [Value of public management and public administration in the process of social transformation]. Publichne upravlinnia: teoriia ta praktyka 3, 41-45 [in Ukrainian].

6. Obolens'kyj O. EF Lukin S. (2013). Publichne upravlinnia: publichna sfera, publichne pravo i publichna polityka-spivvidnoshennia poniat [Public administration: public sphere, public law and public policy-correlation concepts]. Derzhavne upravlinnia ta mistseve samovriaduvannia 2, 3-11 [in Ukrainian].

7. Obushna N. I. (2015). Publichne upravlinnia iak nova model' orhanizatsii derzhavnoho upravlinnia v Ukraini: teoretychnyj aspect [Public management as a new model of organiza- 
tion of governmental management in Ukraine: theoretical aspect]. Efektyvnist' derzhavnoho upravlinnia 44 (1), 53-63 [in Ukrainian].

8. Prykhodchenko L. L. (2010). Sutnist' mekhanizmu zabezpechennia efektyvnoho derzhavnoho upravlinnia. [The essence of the mechanism for ensuring effective public management]. Teoriia ta praktyka derzhavnoho upravlinnia 3, 3-12 [in Ukrainian].

9. Prykhodchenko L. L. (2009). Struktura mekhanizmu derzhavnoho upravlinnia: vzaiemozv'iazok komponentiv ta faktory vplyvu na efektyvnist'. [Structure of the mechanism of public administration: the relationship of components and factors of influence on efficiency]. Visnyk Natsional'noi akademii derzhavnoho upravlinnia pry Prezydentovi Ukrainy 2, 105-112 [in Ukrainian].

10. Sharov Yu. P. (2009). Demokratychni zminy $\mathrm{v}$ publichnomu upravlinni: prohramno-tsil'ova ideolohiia zdijsnennia. [Democratic changes in public administration: program-target ideology of implementation]. Visnyk Akademii mytnoi sluzhby Ukrainy. Ser.: Derzhavne upravlinnia, 1, 52-57 [in Ukrainian].

11. Sharov Yu. E Chykarenko I. (2010). Yevropejs'ki standarty publichnoho upravlinnia: proektsiia na munitsypal'nyj riven'. [European standards for public administration: projection to municipal level]. Derzhavne upravlinnia ta mistseve samovriaduvannia, 295-304 [in Ukrainian].

12. Lerner D., Coleman J. \& Dore $R$. (1968). Modernization [w:] International Encyclopedia of the Social Sciences. NY, Vol. 10 [in English].

13. Fajol' A., Yemeron H., Tejlor I. EF Ford $H$. (1992). Upravlenye - eto iskusstvo [Management - is an art]. Moscow [in Russian]. 